\title{
Sonoko Saito*
}

\section{The Materiality of Ghosts in "The Bench of Desolation” (1910): An Exploration of the Pocket Metaphor}

DOI: http://dx.doi.org/10.12775/LC.2017.005

\begin{abstract}
The article is an analysis of Henry James's “The Bench of Desolation" (1910) from the perspective of the pocket metaphor. The author focuses on one text, referring to interpretations by other scholars, such as Millicent Bell and Martha Banta, and placing the story in a more general context. Saito addresses literary portrayals of men putting hands in their pockets in such works as The Europeans and The Portrait of a Lady. She also discusses the pocket metaphor in The American Scene.
\end{abstract}

Key words: pocket, money, reading and writing, Henry James, “The Bench of Desolation”

\section{Materialność duchów}

\section{w The Bench of Desolation: Analiza metafory kieszeni}

Streszczenie: Artykuł stanowi analizę opowiadania The Bench of Desolation (1910) z perspektywy metaforycznego znaczenia kieszeni. Autorka skupia się na jednym utworze Jamesa, ale omawia go w szerszym kontekście twórczości pisarza. Odwołując się do interpretacji innych badaczy (Millicent Bell i Marthy Banty), Saito odnosi się do literackich obrazów mężczyzn trzymających ręce w kieszeniach w takich utworach, jak Europejczycy i Portret damy. Autorka porusza również aspekt metaforyki kieszeni w The American Scene.

Słowa kluczowe: kieszeń, pieniądze, czytanie i pisanie, Henry James, The Bench of Desolation

* Associate Professor at the Department of International Relations, Faculty of Foreign Studies, the University of Kitakyushu. E-mail: saitos@kitakyu-u.ac.jp. 


\section{Introduction}

his paper focuses on Henry James's "The Bench of Desolation" (1910), ${ }^{1}$ the author's penultimate tale, exploring the practice of reading in relation to the function of pockets. The following analysis seeks to demonstrate that references to pockets in James's stories signal not only detachment from but also involvement in the vulgar, material world. Pockets are suggestive of money and its tenacious grip on life in James's story.

The story was written after James's ten-month tour of the United States from the end of August in 1904 through mid-July of the following year. The novelist traveled to the US after about twenty years of absence, and the impressions he had from this trip to his native land seem to have induced in him a strong sense of alternatives or, in Millicent Bell's words, "innumerable sacrificed possibilities." $\mathrm{He}$ was faced not only by great changes in his home country, but also by ghostly visions of the past. Along with these experiences, the role of money remains an important issue that possessed his analytical mind.

\section{Hidden in the Pocket}

Many of James's major characters, especially men, are often observed putting or keeping their hands in their pockets. This posture is frequently considered to be a sign of detachment, suggesting that the character would rather not be involved and would rather assume the role of a mere observer. Martha Banta gives the example of Robert Acton's posture of keeping his hands in his pockets in The Europeans and regards it "as a sign of fear of commitment." 3 In her exploration of the differences between the stories included in the New York Edition and those omitted from the Edition, Banta argues that

A blandly passive man who keeps his hands in his pockets as a sign of fear of commitment (without the good reasons Ralph Touchett has for this pocket-clenching posture), Acton inspires us to liken him to the passive Frederick Winterbourne (who gets into the Edition by courtesy of Daisy Miller's vibrant presence, not his own), rather than to Lambert Strether, who will later be written up to say "no" with passionate high style. ${ }^{4}$

\footnotetext{
1 "The Bench of Desolation" was published serially in Putnam's Magazine and is one of the five stories included in The Finer Grain.

2 M. Bell, Meaning in Henry James, Cambridge 1991, p. x.

3 M. Banta, Excluded Seven: Practice of Omission, Aesthetics of Refusal, Stanford 1995, p. 246.

4 Ibidem.
} 


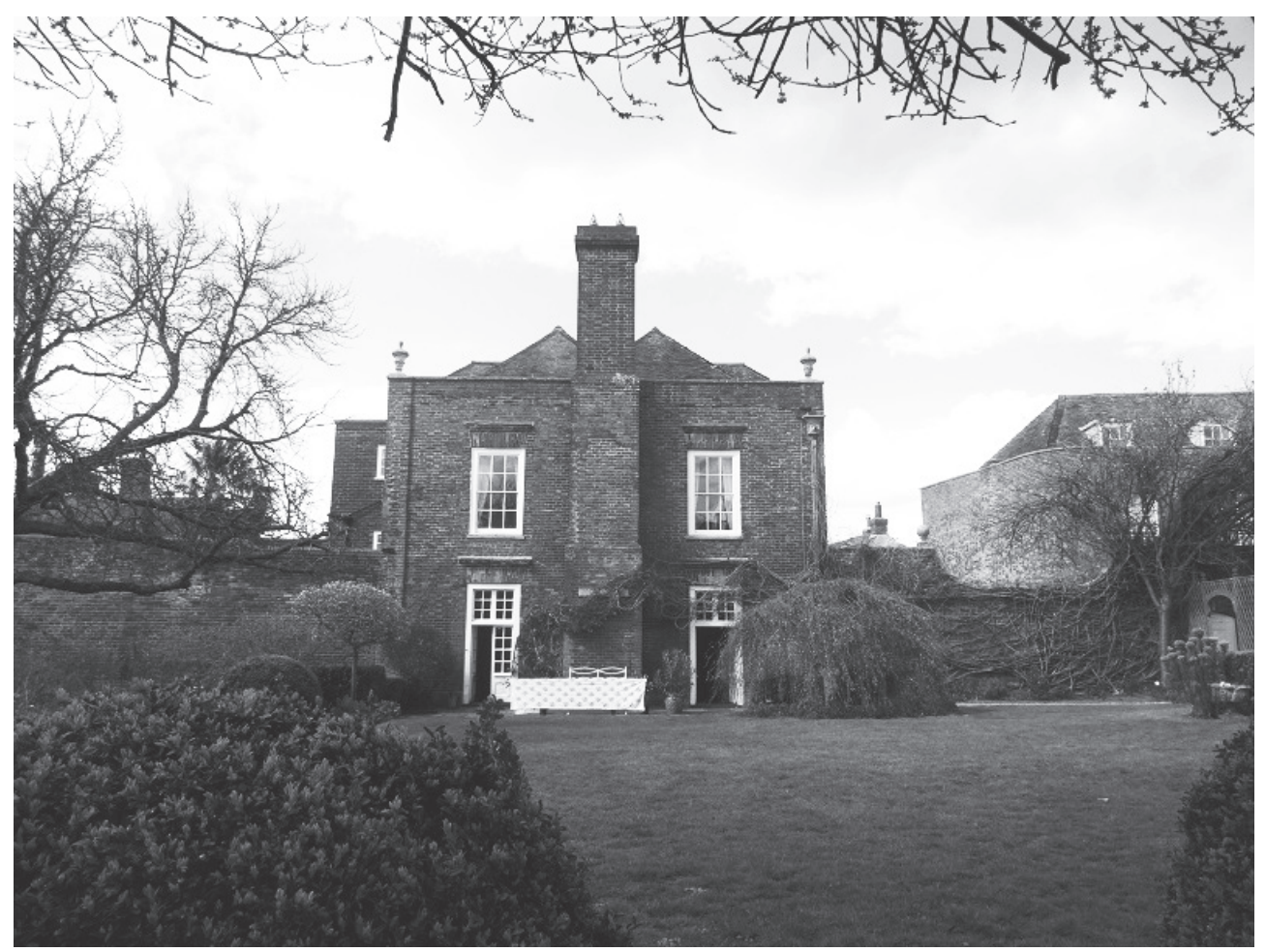

Lamb House. Photo by Sonoko Saito

As this posture is often assumed by male characters who avoid a close, marital involvement with the women they seem to be interested in, Banta's explanation in relating it to passiveness is relevant. Although Banta seems to be emphasizing Ralph Touchett's wish "to provide Isabel with wings" in The Portrait of a Lady, Ralph's gesture can also be explained "as a fear of commitment." The narrator introduces Ralph as a man with his hands in his pockets. This seemingly affectionate and sympathetic character, especially in regard to Isabel Archer, neither withdraws from Isabel's life nor commits himself entirely. In other words, while he continues to be greatly interested in her life throughout the novel, he is in two minds about taking Isabel seriously in terms of marriage. Thus James's male characters, including Ralph, appear to seek the ideal place between involvement and detachment.

It is money that sustains their in-between location. Such male characters as Ralph, Acton, or Winterborne, are all wealthy. Paradoxically, their detachment from materiality is, in fact, made possible by their money, which is the symbol of the vulgar, material world. In addition, Ralph, whose intention is "to provide Isabel with wings" and thus to free her from any material bondage, actually plays the central role in drawing Isabel into the material world. He intends to support Isabel's flight with an endorsement of money-a considerable portion of his inheritance from his father-but the money turns out to bind Isabel firmly to the material world as it draws Gilbert Osmond's attention to her.

5 Ibidem, p. 316. 
A fear of commitment or detachment does not fully explain why James's male characters' hands are thrust into their pockets. Rather, the hands-in-the-pockets posture, which results from their internal struggle to sustain their subtle balance, represents their dependence on money. They consciously or subconsciously put their hands into their pockets, as if to make sure that they possess money.

"The Bench of Desolation" followed the publication of three novels during James's major phase and then also the New York Edition. While R. P. Blackmur may be right in arguing that James was engaged in "a new form of fiction of which the only finished examples are the stories in The Finer Grain," 6 these stories may also be seen as the culmination of his reading and writing career. Exemplifying the latter interpretation, Tomoko Okumura calls "The Bench of Desolation" "a melting pot of various Jamesian themes." In this paper I intend to focus on one aspect: the significance of the hands-in-the-pockets posture.

\section{The Practice of Reading}

In "The Bench of Desolation" the hands-in-the-pocket posture is mainly associated with the female, rather than male, characters. Kate Cookham's pocket is thus described by the narrator at the beginning of the story:

She had practically, he believed, conveyed the intimation, the horrid, brutal, vulgar menace, in the course of their last dreadful conversation, when, for whatever was left him of pluck or confidence-confidence in what he would fain have called a little more aggressively the strength of his position-he had judged best not to take it up. But this time there was no question of not understanding, or of pretending he didn't; the ugly, the awful words, ruthlessly formed by her lips, were like the fingers of a hand that she might have thrust into her pocket for extraction of the monstrous object that would serve best for-what should he call it? —a gage of battle. ${ }^{8}$

The following is another description of Kate's pocket:

The way the ruffians had been "her" ruffians-it appeared as if she had posted them behind her from the first of her beginning her game! — and the way 'instructions' bounced out, with it, at a touch, larger than life, as if she had arrived with her pocket full of them! ${ }^{1}$

Inside her pocket is a "monstrous object" or "instructions" that Herbert thought that her "firm" or "ruffians" have given her in order for her to secure the prospect of a fortune. This image of the pocket appears to have nothing in common with that of the pockets of James's male characters in earlier narratives. However, Kate's pocket has things in common with theirs in that it metaphorically represents a place where a potential threat to money is hidden.

\footnotetext{
6 R. P. Blackmur, Studies in Henry James, New York 1983, p. 123.

7 T. Okumura, "A Study of Henry James," Dynamis 3 (1999), p. 123.

8 H. James, "The Bench of Desolation," in: The Complete Letters of Henry James, A Digireads.com Book, 2010, p. 185.

9 Ibidem, pp. 190-191.
} 
Kate Cookham has been seen by critics: as a "new woman" with "both good and bad qualities"; as one of the "contradictory characters" and survivors in The Finer Grain; ${ }^{10}$ as a "strong woman" and "a flawed character with a mistaken point of view"; ${ }^{11}$ as an "aggressive" and "threatening" 12 person, as "a mysterious figure,"13 or as an "ambiguous apparition." ${ }^{14}$ Kate could be seen as "an apparition" or even as a "ghostly" ${ }^{15}$ being. The story is mystifying for the reader, and this is largely because of Kate. She is difficult to grasp, as she transgresses boundaries, including the gender boundary, blending in with other characters, such as Herbert Dodd and Nan Drury. Joseph Milicia claims that

$[\mathrm{W}]$ hen Kate surprisingly reappears in Chapter IV, it is as if she had materialized from Dodd's mind, the dormant part finally insisting upon its presence. At this point, traditional character analysis of Dodd becomes inadequate, for the remarkable manner in which James describes Kate's reappearance, almost as if she were an emanation from Dodd, implies symbolic possibilities. ${ }^{16}$

Critics have tried to explain the ambiguity of both Kate and the story. Tomoko Okumura writes that "the difficulty in understanding the characters' behavior and decision might puzzle readers: this story is, in a word," too "unreal." ${ }^{17}$ Okumura views this story as a narration that develops around a "story skeleton," 18 and Charon reads it in relation to "the acts of telling." ${ }^{19}$ However, it seems more appropriate to see this story in light of the question of reading and writing, since the story was written by a "self-referential" 20 author who had read his own past works and strenuously revised them, and who was looking back to his own life story.

\section{The Failed Reader: Herbert Dodd}

The story unfolds in a place that is "one of the very last, the far westward benches of the interminable sea-front facing west" ${ }^{21}$ with three characters: Herbert Dodd, Kate Cookham, and Nan Drury. Their relationships can be viewed as mutual reading - the three read each other - and "the bench of desolation" represents the point where their readings meet.

It seems at the beginning that Herbert occupies a place of prestige among the three readers. He owns a book business, which he has inherited from David Geddes, his mater-

\footnotetext{
10 A. R. Tintner, "Four Views of James," Studies in the Novel 11.1 (1979), pp. 111-112.

11 M. D. Springer, A Rhetoric of Literary Character: Some Women of Henry James, Chicago 1978, p. 67.

12 R. S. Lyons, "Ironies of Loss in The Finer Grain," The Henry James Review 11.3 (1990), p. 203.

13 J. Milicia, "Henry James' Winter's Tale:'The Bench of Desolation,"' Studies in American Fiction 6.2 (1978), p. 142.

14 R. Charon, "The Perilous Fate of the Teller, or What Bench? What Desolation?" Literature and Medicine 25.2 (2006), p. 426.

15 J. Milicia, “Henry James' Winter's Tale: 'The Bench of Desolation,"” op. cit., p. 142.

16 Ibidem, p. 147.

17 T. Okumura, "A Study of Henry James," op. cit., p. 122-123.

18 Ibidem, p. 133.

19 R. Charon, "The Perilous Fate of the Teller, or What Bench? What Desolation?" op. cit., p. 415.

20 R. Charon mentions this as one of the characteristics of James's later style (ibidem, p. 416).

21 H. James, "The Bench of Desolation," op. cit., p. 189.
} 
nal uncle. Herbert characterizes himself as having a "natural taste" 22 and a "sense of certain differences." ${ }^{23} \mathrm{He}$ views himself as an "aristocratic" and "elegant" "gentleman." ${ }^{24}$ It appears that he is in the position of choosing his marriage partner between the other two characters, Kate and Nan.

However, Herbert is not a good reader; in fact, he often misreads people, including himself. In his reading of Kate, he interprets her as a "horrid, brutal, vulgar menace," who tries to implicate him in the "vulgarest" process of a lawsuit of "an action for breach." ${ }^{25} \mathrm{Her}$ vulgarity is definite in Herbert's eyes, which makes him avoid her. Herbert describes her face as follows:

There might have been the last ring of an appeal or a show of persistent and perverse tenderness in it, however preposterous any such matter; but in point of fact her large, clean, plain brown face-so much too big for her head, he now more than ever felt it to be, just as her head was so much too big for her body, and just as her hats had an irritating way of appearing to decline choice and conformity in respect to any of her dimensions - presented itself with about as much expression as his own shop-window when the broad, blank, sallow blind was down. ${ }^{26}$

Herbert compares Kate's face to the lowered blind of his shop-window: broad, blank and sallow, lacking expression. He hates the blind at his shop-window, on which his name, "Herbert Dodd, Successor," is written under his uncle's name, because it "might so easily be taken for the mask of failure." ${ }^{27} \mathrm{He}$ hates the blind at the window because it reminds him of his lack of money in spite of his high self-esteem.

This description is like the title page of an old book. Kate, whose face reminds Herbert of his financial dependence, is metaphorically the title page of the book that Herbert never wants to open and read. He feels a chill when Kate imploringly says, "It's just as much my dream as it ever was, Herbert Dodd, to take up mine with you! Remember for me that I can do with it, my dear, that my idea is for even as much as that of you!" and then again "remember that for me, Herbert Dodd; remember, remember!" ${ }^{28}$ It is the same sort of chill that the blind of his shop-window always gives him.

Herbert similarly misreads Nan Drury, who is described as follows:

She had, it was true, forms of speech, familiar watchwords, that affected him as small scratchy perforations of the smooth surface from within; but his pleasure in her and need of her were independent of such things and really almost altogether determined by the fact of the happy, even if all so lonely, forms and instincts in her which claimed kinship with his own. With her natural elegance stamped on her as by a die, with her dim and disinherited individual refinement of grace, which would have made anyone wonder who she was anywhere-hat and veil and feather-boa and smart umbrella-knob and all - with her regular God-given distinction of type, in fine, she couldn't abide vulgarity much more than he could. ${ }^{29}$

\footnotetext{
22 Ibidem, p. 188.

23 Ibidem.

24 Ibidem.

25 Ibidem, p. 185.

26 Ibidem, pp. 186-187.

27 Ibidem, p. 187.

28 Ibidem, p. 186.

29 Ibidem, p. 190.
} 


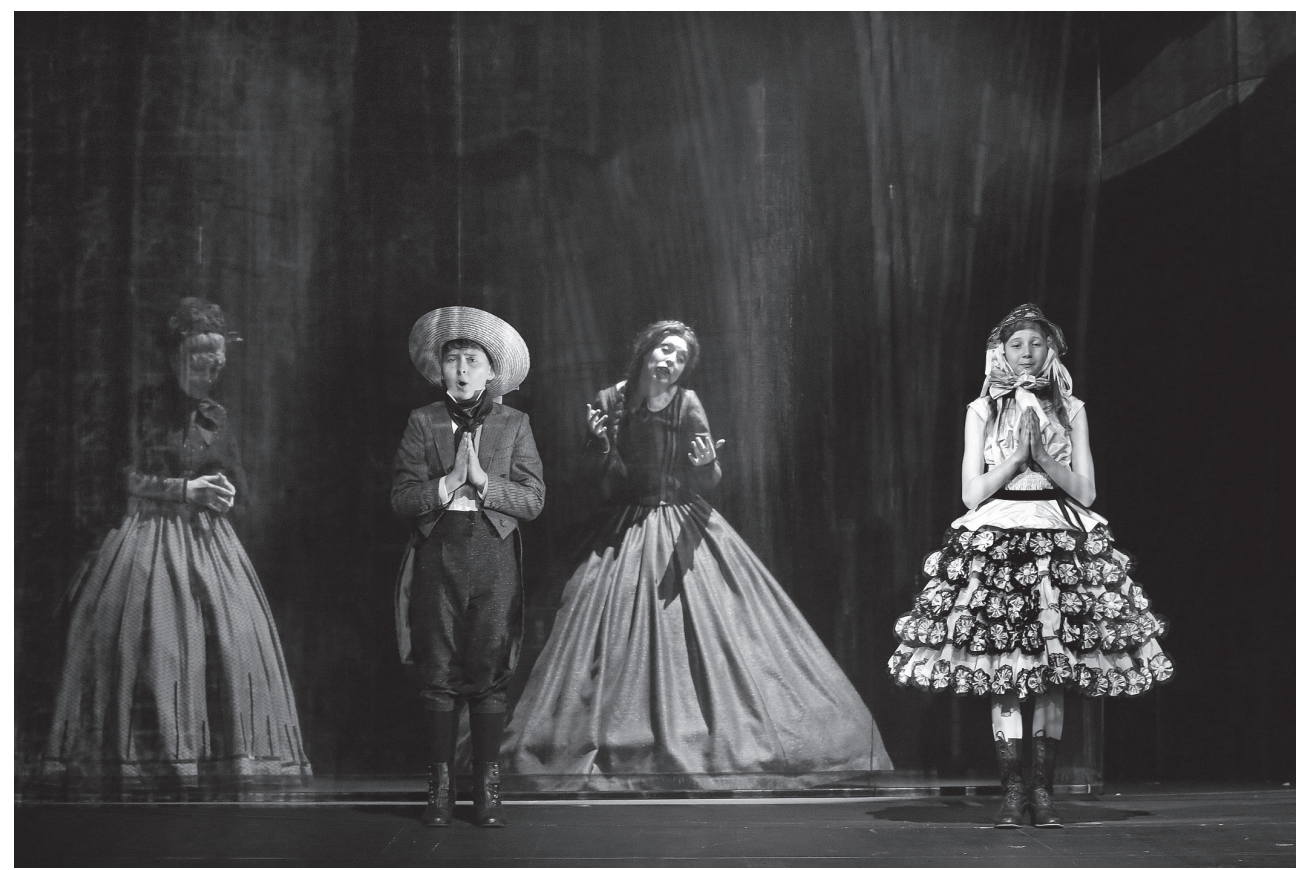

The Turn of the Screw. Photo by Marek Grotowski

From Herbert's perspective, Nan is not an interesting book to read because she merely reproduces forms of speech or familiar watchwords. At the same time, she seems attractive to Herbert because of her appearance, "her natural elegance" and "individual refinement of grace." He believes that Nan shares his view of art and "vulgarity." However, this reading turns out to be a misreading. In her "artless habit," ${ }^{30}$ Nan accuses Herbert later of not understanding his situation as the source of their misery:

"Well, I'm glad I am in your life, terrible as it is, however or whenever I did come in!" and "Of course you'd rather have starved —and it seems pretty well as if we shall, doesn't it? — than have bought her off by a false, abhorrent love, wouldn't you?" and "It isn't as if she hadn't made up to you the way she did before you had so much as looked at her, is it? or as if you hadn't shown her what you felt her really to be before you had so much as looked at $m e$, is it either?" and "Yes, how on earth, pawning the shoes on your feet, you're going to raise another shilling-that's what you want to know, poor darling, don't you?"31

Her reading of the situation turns out to be correct. Herbert's misreading is obvious, and in reality, her reading ability exceeds his. He reads her only through her "veil," her "pretty, dotty, becoming veil,"32 and as a poor reader, he fails to correctly read the "dots" on the veil, the veil that is later worn by Kate.

Ibidem, p. 191.

lbidem.

32 Ibidem, p. 189. 


\section{Double Readers: Nan and Kate}

Herbert has been read by Nan and Kate, and rather accurately. They are not, as it turns out, mere objects of his reading. Nan's accusation proves to be just, and the conversation between Kate and Herbert reveals Kate's superiority as a reader.

"Can you give me your word of honour that I mightn't, under decent advice, have defied you?" It made her turn very white; but now that she had said what she had said she could still hold up her head. "Certainly you might have defied me, Herbert Dodd."

"They would have told me you had no legal case?"

Well, if she was pale she was bold. "You talk of decent advice-?!" She broke off, there was too much to say, and all needless. What she said instead was: "They would have told you I had nothing."

"I didn't so much as ask," her sad visitor remarked.

"Of course you didn't so much as ask."

"I couldn't be so outrageously vulgar," he went on.

"I could, by God's help!" said Kate Cookham.

"Thank you." ${ }^{3}$

Kate and Nan correctly interpret Herbert Dodd, or the "dot." Kate knew that Herbert would agree to settle her lawsuit out of court for four hundred pounds. He only manages to pay her two hundred and seventy pounds and, soon after, becomes destitute when his humble business is seized by creditors.

The two superior readers, Nan and Kate, both potential marriage partners for Herbert, function as doubles. Their duality begins to unfold when Herbert and Kate meet again on the bench. The ghosts of the past are conjured up by Kate's return with money. Kate returns to the bench, after ten years, as if she was joining the "ghost of a bustle" 34 that haunts the bench, or the "ghosts of dead seasons"35 that Herbert watches on the bench.

The identity of this returned Kate overlaps with that of Nan. They share a veil of the same pattern. Before Kate and Herbert separated, Kate was never a lady who "wore pretty, dotty, transparent veils, as Nan Drury did" (187); ${ }^{36}$ yet, when she returns to the bench many years later, the narrator describes Kate's transformation as follows:

And she was—oh, yes—a real lady: a middle-aged person, of good appearance and of the best condition, in quiet but "handsome" black, save for very fresh white kid gloves, and with a pretty, dotty, becoming veil, predominantly white, adjusted to her countenance; which through it somehow, even to his imperfect sight, showed strong fine black brows and what he would have called on the spot character. ${ }^{37}$

In this scene, Kate, the real lady, wears "a pretty, dotty, becoming veil" that Nan had worn before. This uncanny identity of the veil seems to be saying that Kate's veil has been trans-

\footnotetext{
33 Ibidem, p. 206.

34 Ibidem, p. 189.

35 Ibidem, p. 193.

36 Ibidem, p. 187.

37 Ibidem, p. 196.
} 
ferred from Nan. The narrator thus refers to the increasing degree of intimacy between Nan and Herbert:

Here it was that-as well as on whatever other scraps of occasions they could manage-Nan began to take off and fold up and put away in her pocket her pretty, dotty, becoming veil; as under the logic of his having so tremendously ceased, in the shake of his dark storm-gust, to be engaged to another woman. ${ }^{38}$

While becoming intimate with Herbert, Nan puts the veil in her pocket. The next time the veil appears is when it is worn by Kate. Nan, who is dead, is actually resurrected in Herbert's eyes at Kate's offer of money, which is five-fold the amount that he paid to her.

Everything there then was his - to make him ask what had been Nan's, poor Nan's of the constant question of whether he need have collapsed. She was before him, she was between them, his little dead dissatisfied wife; across all whose final woe and whose lowly grave he was to reach out, it appeared, to take gifts. He saw them too, the gifts; saw them — she bristled with themin his actual companion's brave and sincere and authoritative figure, her strangest of demonstrations. But the other appearance was intenser, as if their ghost had waved wild arms; so that half a minute hadn't passed before the one poor thing that remained of Nan, and that yet thus became a quite mighty and momentous poor thing, was sitting on his lips as for its sole opportunity. ${ }^{39}$

In his mind, Nan confronts Herbert by putting herself between Herbert and Kate, as if she could claim her presence by accompanying the transfer of money from Kate to Herbert. The money is about to come back to him fivefold. However, he cannot accept it because there is no way to make up for the ten years of suffering, during which Nan and her two daughters died. The "still-watching face" ${ }^{40}$ under the dotty veil in the last scene belongs to both Kate and Nan.

Herbert's inability as a reader persists until the end of the story. The "dots" on Kate's veil remain mere dots, and they never become letters that make sense to him.

She [Kate] remained as for questions he might ask, but it was well-nigh as if there played through her dotty veil an irrepressible irony for that particular one. ${ }^{41}$

While trying to fathom what Kate has in store, Herbert fails to read her mind.

\section{Life and Money}

Kate's and Nan's lives are both wasted because of Herbert's inability to read people accurately. The veiled Kate, with her identity overlapping with and indistinguishable from

\footnotetext{
38 Ibidem, p. 189.

39 Ibidem, p. 206.

40 Ibidem, p. 213.

41 Ibidem, p. 211.
} 
Nan's, has returned to take revenge on Herbert and to claim him as her own. By showing Herbert a sealed letter "which certif[ies]" the credit she had opened for him at a London bank, ${ }^{42}$ where the amount of twelve-hundred-and-sixty pounds has been deposited, Kate urges Herbert to choose between a life without money and a life without a past. He chooses the latter.

At this he did get up; that was easier than to say—at least with responsive simplicity; and again for a little he looked hard and in silence at his letter; which, at last, however, raising his eyes to her own for the act, while he masked their conscious ruefulness, to his utmost, in some air of assurance, he slipped into the inner pocket of his coat, letting it settle there securely. ${ }^{43}$

He receives the letter with "some air of assurance" and places it in the inner pocket of his coat. He expects there to be a "return" for this act, or an "engagement." 44 "The return" is to reduce his past life and his family's lives to nothing. His life and sufferings turn out to be mere commodities that are exchangeable with money. Kate soothingly says, "Of course you've suffered," 45 while she persuades him to yield to her money. Kate asks whether the life Herbert has led can be replaced with the life he might have had-a possible but impossible life. According to Richard S. Lyons, "[t] he act that redeems his [Herbert's] situation mocks his past life; by accepting Kate's offer he not only acknowledges his terrible misperception but effectively severs his connection with his past, making not only his own suffering but that of others pointless and absurd." ${ }^{46}$ However, Herbert cannot help accepting the money, and his choice proves that he is after all as "outrageously vulgar"47 as he claims Kate was.

He falls into Kate's arms on the bench at the end of the story:

He waited a moment, dropping again on the seat. So, while she still stood, he looked up at her; with the sense somehow that there were too many things and that they were all together, terribly, irresistibly, doubtless blessedly, in her eyes and her whole person; which thus affected him for the moment as more than he could bear. He leaned forward, dropping his elbows to his knees and pressing his head on his hands. So he stayed, saying nothing; only, with the sense of her own sustained, renewed and wonderful action, knowing that an arm had passed round him and that he was held. She was beside him on the bench of desolation. ${ }^{48}$

Herbert is helplessly possessed by the Kate-Nan double in the end. "Too many things" are conjured up when Kate returns with the money. By allowing money to replace his past, Herbert becomes incapable of distinguishing between real life and its alternatives. His sense of himself also collapses in this indistinguishable ghostly reality.

\footnotetext{
42 Ibidem, p. 189.

43 Ibidem, p. 212.

44 Ibidem, p. 210.

45 Ibidem, p. 203.

46 R. S. Lyons, "Ironies of Loss in The Finer Grain," op. cit., p. 209.

47 H. James, "The Bench of Desolation," op. cit., p. 206.

48 Ibidem, p. 213.
} 


\section{Alternative Readings and Life Stories}

James is known for his elaborate revisions, of which the New York Edition is a prime example. Just as Herbert returns to the bench, James also rivisited his published texts. The practice of revision, or continuous rewriting even after publication of one's work, results in the plurality of texts. The practice of revision consists in negotiating an identity between the words that are there and the words that could be there.

The disparity between the earlier text and the later text of "The Bench of Desolation" also represents the disparity between James's earlier and later selves. This disparity marks the plurality of James' life. In this sense, James's writing can be seen as a process of self-reinvention. Through continuous rewriting, James tries to restore a sense of unity with his doubles. Millicent Bell suggests an analogy between word choices and life choices for James:

These ruminative rereadings of his tales and novels look back upon their original composition. They say again and again that James's fiction grew out of a process by which "developments" proposed themselves to him at every step because "really, universally, relations stop nowhere." He had to struggle against the emergence of possibilities that expanded- "exploded," he even said—out of the form he intended. [...] Because he [James] believed that human life was itself a path picked out, like a tapestry design, upon a canvas of innumerable sacrificed possibilities, he could perceive the shadow of paths not chosen in the most clearly determined life-story. It was because he could not subdue the imaginative responses life aroused in him, violating preconceptions and intentions at every turn, that his art remained full of a sense of alternatives. As the reader of his own works, he is aware of their rich progression of possibilities—and we experience this progression in reading him in our turn. It is why, in this most formally selfconscious of writers, we retain the sensation of "life" never quite contained by art. ${ }^{49}$

James's choices in life parallel his struggle in choosing one word among numerous possible words. He is then haunted by the words he has chosen, which keeps him revising, always searching for other, ghostly words. Similarly, his alternative life choices return to him as ghostly figures confronting his "present." In the encounter and confrontation of the alternative selves, the self and the double become indistinguishable, and the negotiation over their identification is endless. We see the alternative choices return in James's later short stories, such as “The Jolly Corner" (1908), whose protagonist Spencer Brydon's 'alter-ego' appears on his return to America after thirty-three years of absence. Spencer confronts the would-have-been life of another choice.

"The Bench of Desolation" deals with a similar confrontation: the juxtaposition of possible life choices with an already lived life. "The Jolly Corner" and "The Bench of Desolation" both end with the male and female protagonists embracing. However, these embraces do not mark a happy conclusion of their union; rather, they seem to symbolize the possession of male characters by an alternative ghostly life. Despite his mortification, Herbert cannot help succumbing to the ghostly life and allowing it to enter into his present, after which he collapses on the bench.

49 M. Bell, Meaning in Henry James, op. cit., p. x. 


\section{Conclusion}

Herbert Dodd is a "dot" that should be interpreted not only by other fictional characters, but also by the reader of the story. It can be said that it is through Herbert that James challenges the reader with the question of whether life and money are interchangeable. The story seems to show James's awareness of the "vulgar" influence of money, which is neither to be overestimated nor completely rejected. Life and money are inseparable, and Herbert's helplessness in the final scene suggests that James leaves the question unanswered.

It would be possible to say that the ambiguous role of the pockets into which many male characters thrust their hands is partly clarified in "The Bench of Desolation," which was written towards the end of James's career. The "monstrous object" stands for the power of money. This image may reflect James's feelings in the days leading up to World War I. In one of his letters to H. G. Wells in 1915, James wrote: "It is art that makes life, makes interest, makes importance." ${ }^{50}$ Lyons observes that "it was perhaps inevitable that he [James] should have found in the redeeming power of the imagination the sole defense against such a collapse of value" as that which occurred at the time of World War I. ${ }^{51}$

Alternatively, modernity might be seen as the source of the monstrous influence. In The American Scene, among other impressions that James had gained during his travels in the US, he associates modernity with money, creating the image of modernity "with its pockets full of money" ${ }^{52}$ in the following quotation:

The place is inevitably, to-day, but a qualified Sleepy Hollow-the Sleepy Hollow of the author's charming imagination was, as I take it, off somewhere in the hills, or in some dreamland of old autumns, happily unprofanable now; for "modernity," with its terrible power of working its will, of abounding in its sense, of gilding its toy-modernity, with its pockets full of money and its conscience full of virtue, its heart really full of tenderness, has seated itself there under pretext of guarding the shrine. ${ }^{53}$

The pocket metaphor appears also in James's description of the Saco River in The American Scene. In this context the pocket connotes the influence of the material world. The Saco "was the great, gay river, singing as it went, like some reckless adventurer, good-humoured for the hour and with his hands in his pockets, that argued the whole case and carried everything assentingly before it." ${ }^{44}$ Behind the river's grandness hides a dependence on money.

The monetary grip on life that is suggested by the hands-in-the-pocket posture in James's later works is also evident in his earlier fiction. In The Portrait of a Lady Ralph has the countenance of a detached observer when he puts his hands into his pockets. Without money, he could not possibly sustain Isabel's "flight," or his own "aristocratic" way of living. Even earlier, in Watch and Ward, James's first novel, Rodger Lawrence puts his money into his pocket in the first chapter. The male ward "pocket[s] his note and [rises] to his feet." 55

50 Henry James Letters, vol. 4, Cambridge 1984, p. 770.

1 R. S. Lyons, "Ironies of Loss in The Finer Grain," op. cit., p. 210.

52 H. James, The American Scene, New York 1994, p. 117.

53 Ibidem (my emphasis).

54 Ibidem, p. 25.

5 H. James, Watch and Ward, London 1960, p. 24. 
Thus pockets and the act of pocketing various objects emerge as signs not only of detachment but also of involvement in the material world.

In "The Bench of Desolation," money is handled by a woman and given to a man, who is watched over and finally claimed by the same woman. In this regard, the story also signals gender indeterminacy. Since the roles of men and women are interchangeable, Herbert does not know what role he should play.

\section{Bibliography}

Banta, Martha. "Excluded Seven: Practice of Omission, Aesthetics of Refusal". In: Henry James's New York Edition - The Construction of Authorship, ed. David McWhirter. Stanford, California: Stanford University Press, 1995.

Bell, Millicent. Meaning in Henry James. Cambridge: Harvard University Press, 1991.

Blackmur, R. P. Studies in Henry James. New York: New Directions, 1983.

Charon, Rita. "The Perilous Fate of the Teller, or What Bench? What Desolation?". Literature and Medicine 25.2 (2006).

James, Henry. Watch and Ward; with an introduction by Leon Edel. London: Hart-Davis, 1960.

—. Henry James Letters. Vol. 4. Ed. Leon Edel. Cambridge: Harvard University Press, 1984.

-. The American Scene. Ed. John F. Sears. New York: Penguin Books, 1994.

-. The Portrait of a Lady. Ed. Robert D. Bamberg. New York: Norton, 1995.

-. "The Bench of Desolation." In: The Complete Tales of Henry James (Volume 12 of 12). A Digireads. com Book, 2010.

Lyons, Richard S. "Ironies of Loss in The Finer Grain." The Henry James Review 11.3 (1990).

Milicia, Joseph. "Henry James' Winter's Tale: 'The Bench of Desolation.” Studies in American Fiction $6.2(1978)$.

Okumura, Tomoko. "A Study of Henry James: Acquiescence around 'The Bench of Desolation': The Theme and Narrative." Dynamis 3 (1999).

Springer, Mary Doyle. A Rhetoric of Literary Character: Some Women of Henry James. Chicago: University of Chicago Press, 1978.

Tintner, Adeline R. "Four Views of James." Studies in the Novel 11.1 (1979). 